\title{
Insights Into the Pathobiology of Pulmonary Hypertension
}

Victor I. Peinado, Isabel Blanco, Olga Tura-Ceide and Joan Albert Barberà

Department of Pulmonary Medicine, Hospital Clinic, Institut d'Investigacions Biomèdiques August Pi i Sunyer (IDIBAPS), University of Barcelona, Barcelona, Spain; Biomedical Research Networking Center on Respiratory Diseases (CIBERES), Madrid, Spain

\section{ABSTRACT}

Pulmonary hypertension is a complex disorder defined by an abnormal increase of pulmonary arterial pressure that may result in right ventricular failure and death. Pulmonary hypertension has a multifactorial aetiology and is currently classified into five groups based on histopathological appearance and treatment modalities. Our understanding of the pathobiology of pulmonary hypertension has evolved enormously in recent years. A condition that in the past was considered mainly determined by increased vascular tone is now seen as a vasculopathy in which structural changes are driven by excessive cell growth. In the present review we analyse mechanisms that may contribute to the pathobiology of pulmonary hypertension, including imbalance between vasoactive mediators, altered cell proliferation and apoptosis, dysfunctional endothelial repair and angiogenesis, and contributing factors such as inflammation. (BRN Rev. 2015;1:63-77)

Corresponding author: Joan A. Barberà, jbarbera@clinic.ub.es

Key words: Apoptosis. Cell proliferation. Growth factors. Pulmonary artery wall. Vasoactive mediators.

\section{INTRODUCTION}

Pulmonary hypertension $(\mathrm{PH})$ is defined by an abnormal increase of pulmonary arterial pressure that may progress in right ventricular impairment, right ventricular failure, and

\section{Correspondence:}

Joan A. Barberò

Servei de Pneumologia, Hospital Clínic

Villarroel, 170

08036 Barcelona, Spain

E-mail: jbarbera@clinic.ub.es death. Pulmonary hypertension is a progressive disease of multifactorial aetiology, currently classified into five groups based on histopathological appearance and treatment modalities: (i) pulmonary arterial hypertension (PAH), (ii) PH due to left heart disease, 
TABle 1. Classification of pulmonary hypertension
1. Pulmonary arterial hypertension
- Idiopathic PAH
- Heritable PAH
- Drug and toxin induced
- Associated with:
- Connective tissue disease
- HIV infection
- Portal hypertension
- Congenital heart diseases
- Schistosomiasis

1 '. Pulmonary veno-occlusive disease and/or pulmonary capillary hemangiomatosis

1". Persistent pulmonary hypertension of the newborn

2. Pulmonary hypertension due to left heart disease

- Left ventricular systolic dysfunction

- Left ventricular diastolic dysfunction

- Valvular disease

- Congenital/acquired left heart inflow/outflow tract obstruction and congenital cardiomyopathies

3. Pulmonary hypertension due to lung diseases and/or hypoxia

Chronic obstructive pulmonary disease

- Interstitial lung disease

- Other pulmonary diseases with mixed restrictive and obstructive pattern

- Sleep-disordered breathing

- Alveolar hypoventilation disorders

- Chronic exposure to high altitude

Developmental lung diseases

4. Chronic thromboembolic pulmonary hypertension

5. Pulmonary hypertension with unclear multifactorial mechanisms

- Hematologic disorders: chronic haemolytic anaemia, myeloproliferative disorders, splenectomy

- Systemic disorders: sarcoidosis, pulmonary histiocytosis, lymphangioleiomyomatosis

- Metabolic disorders: glycogen storage disease, Gaucher disease, thyroid disorders

- Others: tumoral obstruction, fibrosing mediastinitis, chronic renal failure, segmental pulmonary hypertension

Adopted in the $5^{\text {th }}$ World Symposium on Pulmonary Hypertension, Nice $2013^{1}$ HIV: human immunodeficiency virus; PAH: pulmonary arterial hypertension. (iii) PH due to lung diseases and/or hypoxia, (iv) chronic thromboembolic $\mathrm{PH}(\mathrm{CTEPH})$, and (v) $\mathrm{PH}$ with unclear or multifactorial mechanisms $^{1}$ (Table 1).

Pulmonary hypertension develops as a consequence of the increase of pulmonary vascular resistance produced by the reduction of effective surface in pulmonary vessels. Two major mechanisms account for such a reduction: occlusion by chronic thrombotic lesions or narrowing by the remodelling of the vessel wall. By far, remodelling of resistance vessels is the major determinant of increased pulmonary vascular resistance in the different forms of $\mathrm{PH}$.

In the present review we will address the different cellular and molecular mechanisms underlying the remodelling process of pulmonary vessels and account for the development of $\mathrm{PH}$.

\section{VASOACTIVE MEDIATORS}

The endothelium plays a key role in regulating the reduced vascular tone of pulmonary circulation and controlling cell proliferation in the vessel wall. Vascular tone is governed by the balanced release of endothelium-derived vasoactive agents with either vasoconstrictive or vasodilator properties (Fig. 1). Different signalling pathways have been identified as potential mechanisms that may produce a vasoconstrictive/vasodilator imbalance and contribute to the development of $\mathrm{PH}$.

\section{Nitric oxide pathway}

Nitric oxide (NO) is synthesized in the endothelial cell from L-arginine by the action of 


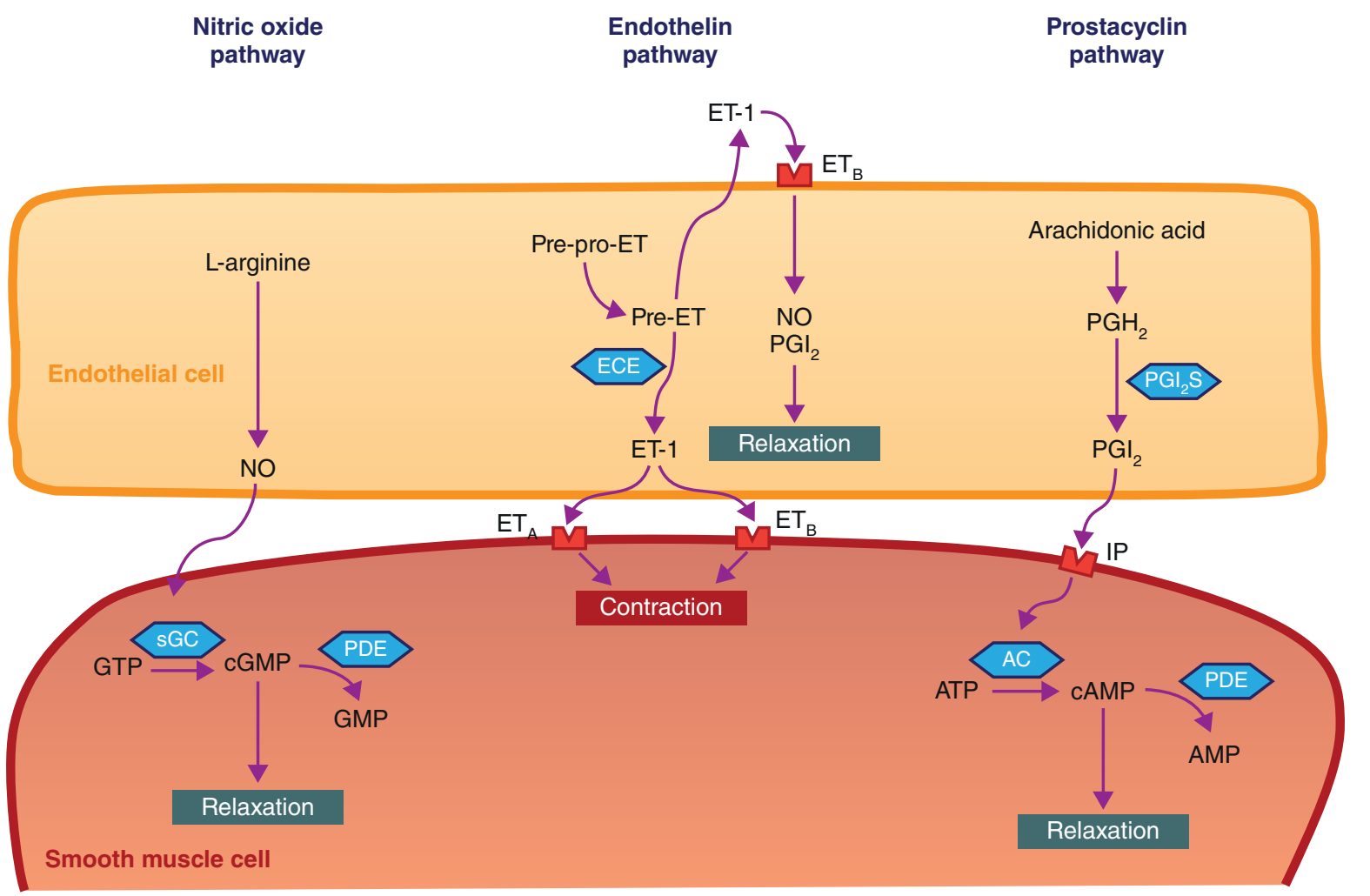

FIGURE 1. Major pathways involved in the regulation of pulmonary vascular tone that conform current targets for pulmonary hypertension treatment. Substances with vasorelaxing action also possess antiproliferative effects on smooth muscle cells, whereas vasoconstrictive agents promote their proliferation.

AC: adenylate cyclase; AMP: adenosine monophosphate; ATP: adenosine triphosphate; cAMP: cyclic AMP; cGMP: cyclic GMP;

ECE: endothelin converting enzyme; eNOS: endothelial nitric oxide synthase; ET: endothelin; ETA: endothelin receptor A;

ETB: endothelin receptor B; GMP: guanosine monophosphate; GTP: guanosine triphosphate; IP: prostaglandin I receptor; NO: nitric oxide; PDE: phosphodiesterase; $\mathrm{PGH}_{2}$ : prostaglandin $\mathrm{H}_{2}$; $\mathrm{PGI}_{2}$ : prostacyclin; $\mathrm{PGI}_{2} \mathrm{~S}$ : prostacyclin synthase; sGC: soluble guanylate cyclase.

endothelial nitric oxide synthase (eNOS) (Fig. 1). In smooth muscle cells (SMCs) of the vessel wall, NO activates soluble guanylate cyclase (sGC) that converts guanosine triphosphate (GTP) to cyclic guanosine monophosphate (cGMP). Cyclic GMP exerts a number of actions through protein kinase G (PKG)-dependent mechanisms, or through other pathways related to regulated ion channels or phosphodiesterases. Cyclic GMP is degraded to 5'GMP by the action of phosphodiesterases (PDE), in particular PDE-5, which is abundantly expressed in the lung ${ }^{2}$. Major effects of cGMP are vasodilation, inhibition of platelet aggregation, and anti-remodelling, anti-apoptotic and anti-inflammatory effects.

Patients with PH show reduced expression of eNOS $^{3}$ and increased levels of asymmetric dimethyl-arginine (ADMA), an endogenous 
competitive inhibitor of eNOS 4 . Currently, the NO signalling pathway is a major target for the treatment of PH by means of PDE-5 inhibitors, such as sildenafil and tadalafil ${ }^{5}$, or sGC stimulators (riociguat) ${ }^{6}$, both resulting in a net increase of the bioavailability of cGMP.

\section{Endothelin pathway}

Endothelin-1 (ET-1) is also synthesized in the endothelial cell and regulates vascular tone by activating $\mathrm{ET}_{\mathrm{A}}$ and $\mathrm{ET}_{\mathrm{B}}$ receptors located on pulmonary artery SMCs, acting as potent vasoconstrictor and inducing cell proliferation (Fig. 1). The expression of ET-1 is increased in lungs of patients with $\mathrm{PH}^{7}$, and circulating levels of ET1 are also increased in patients with $\mathrm{PH}^{8}$. In addition to its vasoconstrictor effect, ET-1 can also induce fibrotic changes by interacting with metalloproteinase ${ }^{9}$. The $\mathrm{ET}_{\mathrm{B}}$ receptor is also present on endothelial cells and is involved in the release of $\mathrm{NO}$ and prostacyclin, thereby producing a vasodilator effect.

The endothelin pathway is also a major target for the current treatment of $\mathrm{PH}$ with the use of dual $\mathrm{ET}_{\mathrm{A}}$ and $\mathrm{ET}_{\mathrm{B}}$ receptor antagonists (bosentan, macitentan), or selective $\mathrm{ET}_{\mathrm{A}}$ receptor antagonists (ambrisentan) $)^{5,10}$.

\section{Prostacyclin pathway}

In the endothelial cell, prostaglandin $\mathrm{H}_{2}\left(\mathrm{PGH}_{2}\right)$ is generated from arachidonic acid by fatty acid cyclooxygenase. Prostaglandin $\mathrm{H}_{2}$ is a substrate for prostacyclin synthase to generate prostacyclin $\left(\mathrm{PGI}_{2}\right)$. In SMCs, $\mathrm{PGI}_{2}$ binds to the prostaglandin $\mathrm{I}_{2}$ receptor (IP) that activates adenylate cyclase $(\mathrm{AC})$ to produce cyclic adenosine monophosphate (cAMP) that in turn activates protein kinase A (PKA), which produces a vasodilator effect, inhibits platelet aggregation, and exerts antiproliferative effects (Fig. 1). Prostacyclin synthase expression is reduced in lungs of patients with severe $\mathrm{PH}^{11}$.

Prostaglandin $\mathrm{H}_{2}$ may also be the substrate of thromboxane $\mathrm{A}_{2}\left(\mathrm{TXA}_{2}\right)$ through the action of thromboxane synthase. Thromboxane $A_{2}$ stimulates vasoconstriction and platelet aggregation via thromboxane/PG receptors.

The prostacyclin pathway is also a current target for PH treatment. Synthetic prostacyclin (epoprostenol) and prostacyclin analogues (iloprost, treprostinil) are given to patients with PH to enhance cAMP-PKA activity and exert vasodilator and antiproliferative effects. Recently, non-prostanoid agonists of the IP receptor have been developed (selexipag) and tested in randomized controlled trials ${ }^{12}$.

\section{Serotonin pathway}

Serotonin or 5-hydroxytryptamine (5-HT) is a neurotransmitter that may act as vasoconstrictor and prothrombotic agent. Serotonin production is increased in $\mathrm{PH}^{13}$. Most of the cardiovascular effects of serotonin are mediated through their binding to the $5-\mathrm{HTB}_{2}$ receptor. Stimulation of the $5-\mathrm{HTB}_{2}$ receptor causes vasoconstriction and stimulation of fibroblasts, which may produce remodelling of pulmonary vessels and fibrotic changes in cardiac valves. Indeed, stimulators of the $5-\mathrm{HTB}_{2}$ receptor, such as appetite suppressants (fenfluramine, aminorex), may produce $\mathrm{PH}$ and cardiac valve disease. 
Whereas in experimental models $5-\mathrm{HTB}_{2}$ receptor antagonists have shown to reduce $\mathrm{PH}^{14}$, in humans a phase II study with the $5-\mathrm{HTB}_{2}$ receptor antagonist terguride was not associated with clinical or hemodynamic improvements in patients with $\mathrm{PAH}^{15}$.

\section{Potassium and calcium channels}

The concentration of free calcium ions $\left(\mathrm{Ca}^{2+}\right)$ in the cytoplasm is an important determinant of contraction, migration, and proliferation in SMC. Abnormalities in both potassium $\left(\mathrm{K}^{+}\right)$and $\mathrm{Ca}^{2+}$ channels have been linked to increased pulmonary vasoconstriction, dysregulation of vascular cell homeostasis, and proliferation of SMCs in $\mathrm{PH}^{16,17}$. Pulmonary artery SMCs from patients with $\mathrm{PH}$ may show a selective downregulation of voltage-gated $\mathrm{K}^{+}(\mathrm{Kv})$ channels, which is associated with opening of voltage-gated $\mathrm{Ca}^{2+}$ channels, increased $\mathrm{Ca}^{2+}{ }^{2 y-}$ toplasmic concentration, and induction of SMC contraction ${ }^{18}$.

Transient receptor potential channels (TRPC) may contribute to the intracellular influx of $\mathrm{Ca}^{2+}$ and are associated with proliferation of SMCs. The TRCP3 and TRCP6 are upregulated in pulmonary artery SMCs from patients with $\mathrm{PH}^{19}$.

Currently, $\mathrm{Ca}^{2+}$ channel blockers are used to treat a reduced group of patients with idiopathic PAH who show positive response in the acute vasoreactivity testing 5 . Exploration of other ways to manipulate $\mathrm{Ca}^{2+}$ signalling pathways by means of $\mathrm{Kv}$ gene therapy, dichloroacetate, or anti-survivin are currently under way ${ }^{20}$.

\section{CELL PROLIFERATION}

Arterial obliteration by vessel remodelling is a hallmark of $\mathrm{PH}$ pathogenesis ${ }^{21}$. Vascular remodelling involves all layers of the vessel wall. Each compartment of the pulmonary arterial wall entitles a wide range of cellular heterogeneity, which further enhances the remodelling process ${ }^{21}$. A common feature to all forms of $\mathrm{PH}$ remodelling is the formation of a layer of smooth muscle-like cells (or myofibroblasts) embedded in extracellular matrix, between the endothelium and the internal elastic lamina, termed the neointima. In addition, clusters of hyperproliferative endothelial cells resembling small tumours further expand the wall of the compromised pulmonary artery ${ }^{22,23}$.

The specific biological processes in each $\mathrm{PH}$ type that enable vessel remodelling are unclear, but there is evidence to involve changes in SMC/endothelial cell differentiation, migration, proliferation, and apoptosis. Of all, cell proliferation has been more extensively investigated in PH. Pulmonary artery SMC and endothelial cells are characterized by a pro-proliferative and anti-apoptotic phenotype $\mathrm{e}^{24}$.

\section{Growth factors}

Growth factors are key players in the regulation of cell proliferation in $\mathrm{PH}$. Several growth factors, including platelet-derived growth factor $(\mathrm{PDGF})^{25,26}$, epidermal growth factor (EGF) ${ }^{27}$, and vascular endothelial growth factor (VEGF) ${ }^{28}$, have been implicated in the abnormal proliferation and migration of pulmonary artery vascular cells (Fig. 2). These factors act as potent mitogens and chemoattractants for 


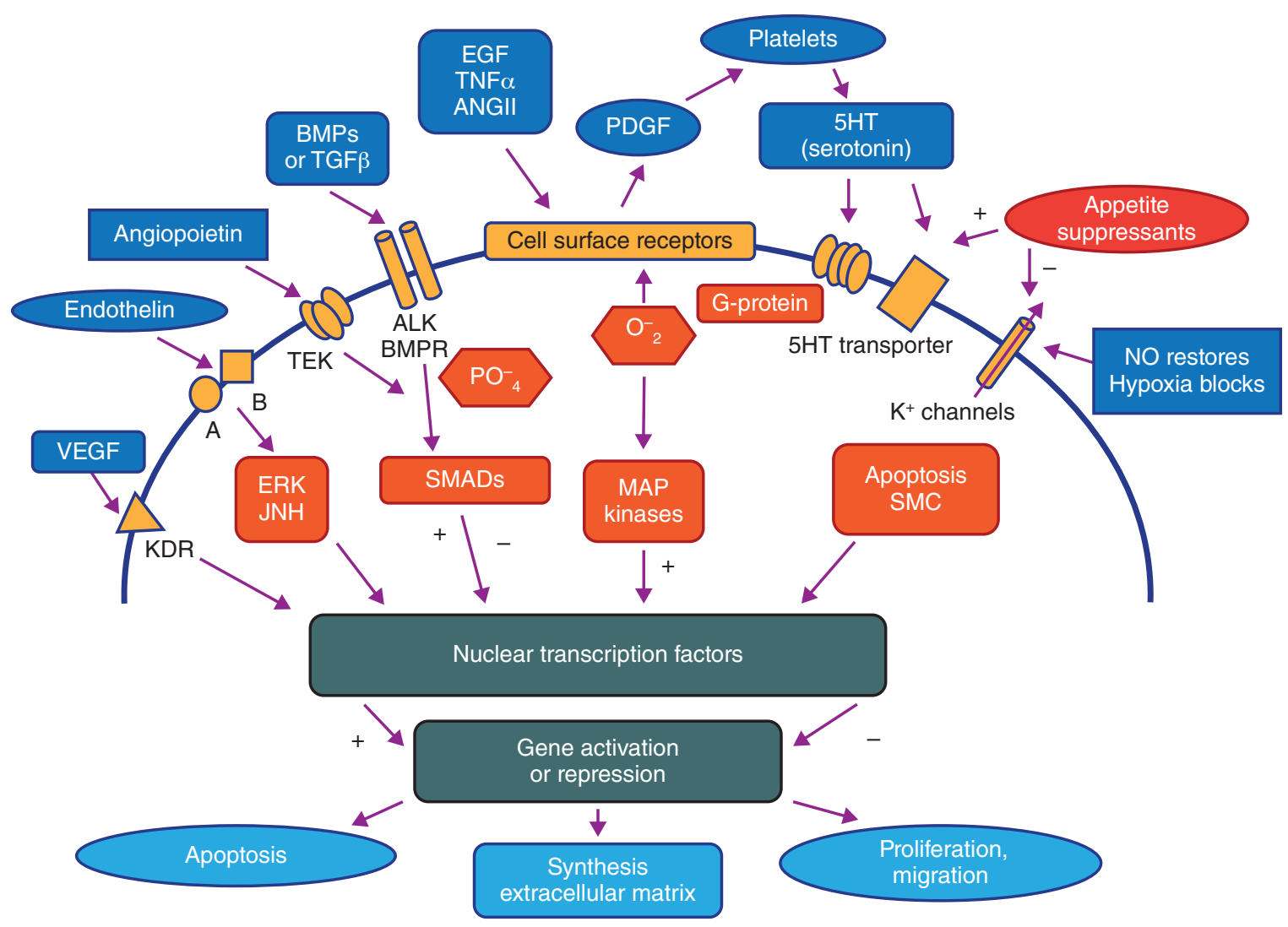

FIgURE 2. Major mediators in pulmonary hypertension pathophysiology.

ALK: activin-like receptor kinase; BMP: bone morphogenetic protein; BMPR: bone morphogenetic protein receptor;

EGF: epidermal growth factor; 5HT: 5-hydroxytryptamine; KDR: kinase insert domain receptor; MAP: mitogen-activated protein;

SMAD: mothers against decapentaplegic; SMC: smooth muscle cell; TGF: transforming growth factor; TNF: tumour necrosis factor;

VEGF: vascular endothelial growth factor.

fibroblasts, SMCs, and endothelial cells and cause resistance to apoptosis.

Although there is consensus of a role of VEGF in $\mathrm{PH}$, the pathogenic role of VEGF could be dependent on its isoform. The VEGF expression is upregulated within the pulmonary vasculature, as well as in plexiform lesions ${ }^{29}$. However, a recent study identified a pathogenic role for VEGF-B. Unlike VEGF-A, VEGF-B appears to exacerbate remodelling in VEGF-B knockout mice (VEGF-B ${ }^{-/-}$) exposed to chronic hypoxia. They exhibit significantly less pulmonary vascular remodelling compared with wild-type mice (VEGF-B $\left.{ }^{+/+}\right)^{30}$.

Other growth factors including PDGF, basic fibroblast growth factor (FGF), insulin-like growth factor-1, and EGF have also been implicated in the development of remodelling and all have been reported to be increased in $\mathrm{PH}$. The mechanism that leads to induction 
of these growth factors in the pulmonary vasculature is unclear. Recent studies have shown that reactive oxygen species play an important role in $\mathrm{PH}$. Hypoxia, mechanical stretch, shear stress, and hydrogen peroxide have the capacity to induce PDGF expression in human pulmonary endothelial cells.

Receptor tyrosine kinases for growth factors form potential targets for $\mathrm{PH}$ treatment. The tyrosine kinase inhibitor imatinib reverses vessel remodelling in experimental $\mathrm{PH}^{26}$. The effects of imatinib have been evaluated in a multicenter, randomized controlled trial in patients with PAH. Results show that imatinib improves pulmonary haemodynamics, symptoms, and exercise tolerance in $\mathrm{PAH}^{31}$. However, imatinib has not been approved for $\mathrm{PAH}$ treatment due to serious adverse effects. Along with this, nilotinib, a second generation tyrosine kinase inhibitor, EGF receptor blockers and FGF receptor inhibitors have been shown to attenuate $\mathrm{PH}$ in experimental models ${ }^{32,33}$.

Angiopoietin-1 is an angiogenic factor essential for lung vascular development ${ }^{34}$. Highly expressed by SMCs, angiopoietin-1 stabilizes the development of blood vessels by recruiting muscle cells, inducing cellular migration and division, enhancing the formation of endothelial tubes, and creating mature arterial structures. Interestingly, evidence suggests that all forms of non-familial PH are characterized by the upregulation of angiopoietin-1, correlating directly with the severity of the disease $^{34}$. Furthermore, angiopoietin-1 can stimulate endothelial cells to produce and secrete serotonin $(5-\mathrm{HT})^{35}$. These findings suggest that $\mathrm{PH}$ occurs through an angiopoietin-1/TIE2/5-HT paracrine pathway.

\section{Apoptosis}

Several abnormalities that have been described in $\mathrm{PH}$ contribute to a proliferation-apoptosis imbalance and to resistance to apoptosis within the vascular wall and may explain the remodelling in pulmonary arteries. Survivin, a member of the inhibitor of apoptosis gene family, is involved in cell proliferation and promotes cell survival in cancer by blocking programmed cell death. Survivin exhibits differential expression in nearly all human cancers, but not in normal tissues ${ }^{36}$. In cancer, inhibition of survivin reduces cell proliferation, increases apoptosis, and sensitizes cells to cytotoxic agents and radiotherapy. The administration of the pro-apoptotic sphingolipid ceramide (encapsulated nanoliposomes) reduces the expression of survivin and cures a type of leukaemia of natural killer cells (NK-LGL leukaemia) in an experimental rat model ${ }^{37}$. Likewise, treatment with sepantronium bromide (YM155), a new survivin inhibitor, or other anti-survivins have therapeutic efficacy, leading to apoptosis and inhibition of the proliferation in SK-NEP-1 Wilms tumour ${ }^{38}$. Phase I and II studies have shown that the administration of YM155 is safe, reaches plasma concentrations, and has antitumor activity in patients with different types of solid tumours ${ }^{39,40}$.

Survivin is expressed in pulmonary arteries of patients with $\mathrm{PAH}$, but not in control subjects ${ }^{41}$. Accordingly, it has been hypothesized that the survivin signalling pathway may play a pivotal role in cell proliferation and cell division, thereby contributing to the development of $\mathrm{PAH}^{41,42}$. In vitro, survivin inhibition induces pulmonary artery SMC apoptosis and reduces its proliferation ${ }^{41}$. In rats with 
monocrotaline-induced $\mathrm{PH}$, survivin is overexpressed in pulmonary artery SMCs and its inhibition with the nebulization of an adenovirus carrying a survivin suppressor mutant prolongs their survival ${ }^{41}$, thereby suggesting that the survivin pathway could be a potential therapeutic target in $\mathrm{PH}$.

\section{GENETIC MECHANISMS}

Pulmonary arterial hypertension is a complex disease with both genetic and environmental components. In idiopathic PAH, about $75 \%$ of the cases are sporadic and about $25 \%$ are familial. Inheritance of heritable PAH appears to be autosomal dominant with a penetrance of approximately $20 \%$, suggesting that the mutation alone is insufficient to result in expression of the disease phenotype.

Bone morphogenetic protein receptor type 2 (BMPR2) is a member of the transforming growth factor beta (TGF- $\beta$ ) superfamily, a group of serine kinase transmembrane signals that have also been implicated in other pathologies. The BMPR2 receptor was originally described to be involved in the regulation of growth and differentiation of bone and cartilage ${ }^{43}$, but more recently, it was also shown to play a critical role in the regulation of growth, differentiation, and apoptosis of other cell types including endothelial cells and pulmonary artery $\mathrm{SMCs}^{44}$ (Fig. 3). The BMPR2 mutation is present in more than $50 \%$ of heritable PAH. The gene is located on the long arm of chromosome $2(2 \mathrm{q} 31,32)$ has 13 exons, and 298 mutations have been described at different points ${ }^{45}$. A phenomenon of genetic anticipation occurs, meaning that later generations have the disease at younger ages.
Patients with the mutated gene have also some differences from those without: worse hemodynamic profile and less response to acute vasodilator test; however, there are no differences in survival and clinical characteristics at diagnosis ${ }^{46}$.

In recent years there have been great advances in this field and other rare mutations in $\mathrm{PAH}$ have been described, mainly genes belonging to the TGF- $\beta$ superfamily: activin-like receptor kinase-1 (ALK1), endoglin (ENG), and mothers against decapentaplegic 9 (SMAD9) (7-50. $^{4}$. Also, mutations have been described in caveolin-1 (CAV1) $)^{51}$, which encodes a membrane protein of caveolae, abundant in the endothelial cells of the lung, and $\mathrm{KCNK} 3$, a gene encoding potassium channel super family $\mathrm{K}$ member- $3^{52}$.

\section{ENDOTHELIAL REGENERATION AND ANGIOGENESIS}

The endothelium is considered a genetically stable, quiescent cell line that plays a critical role in the regulation and maintenance of vascular homeostasis. It acts as a non-adhesive surface for platelets and leukocytes and produces important factors in the regulation of inflammation, thrombosis, and blood flow $^{53}$. Despite the uncertainty of the exact mechanisms causing $\mathrm{PH}$, the current belief suggests that an injury occurring in a genetically predisposed individual could initiate microvascular degeneration or result in proliferative apoptosis-resistant endothelial cells ${ }^{54}$. Endothelial dysfunction favours an increase in vascular tone and mediates structural changes in the pulmonary vasculature and drives an abnormal endothelial cellular 


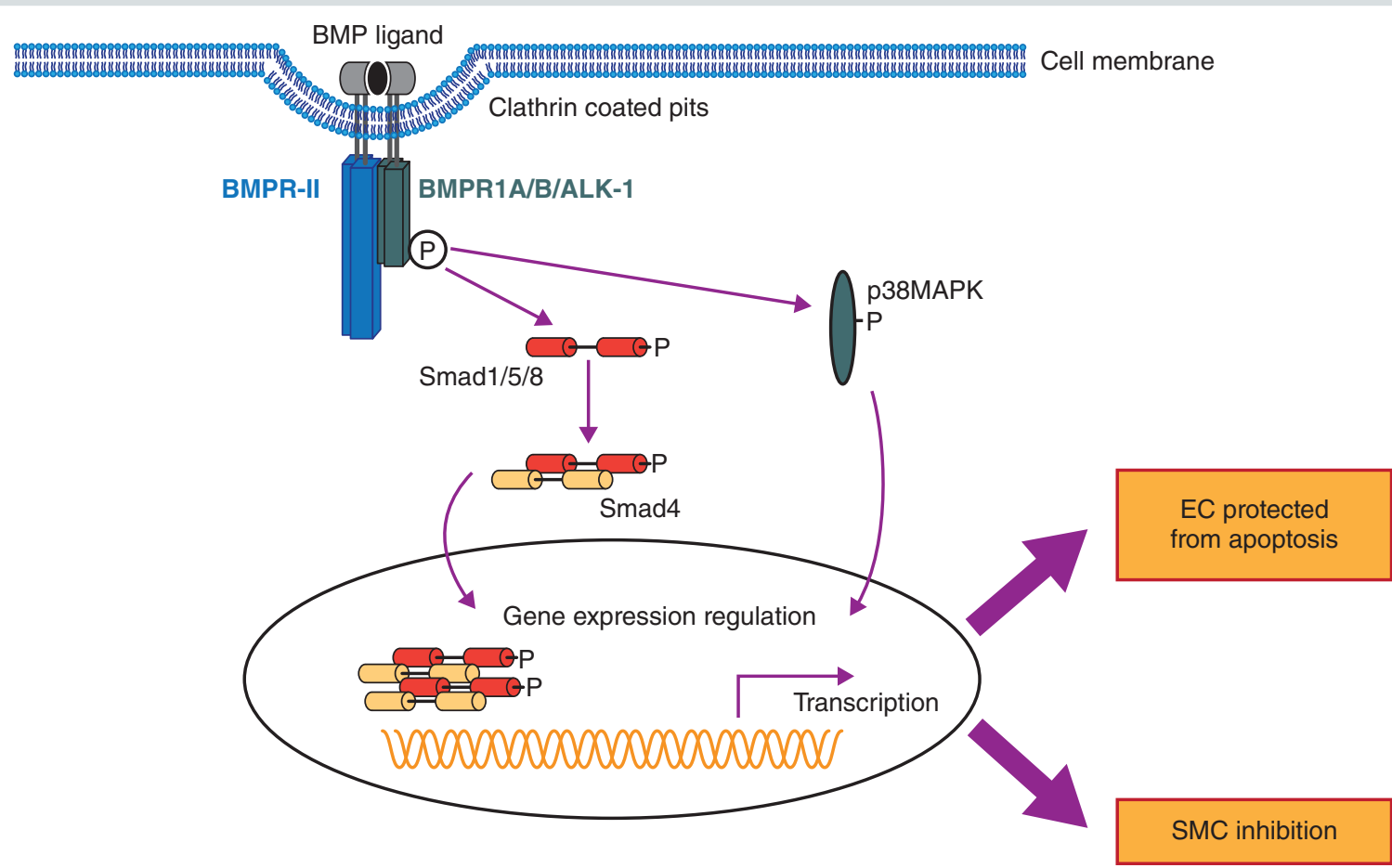

Figure 3. Bone morphogenetic protein-2 signalling pathway. Signalling in the bone morphogenetic protein pathway begins with the binding of a bone morphogenetic protein to the type II receptor. This causes the recruitment of a bone morphogenetic protein type I receptor, which it phosphorylates. The type I receptor phosphorylates a receptor-mothers against decapentaplegic a transcriptional regulator. ALK: activin-like receptor kinase; BMP: bone morphogenetic protein; BMPR: bone morphogenetic protein receptor; EC: endothelial cell; MAPK: mitogen-activated protein kinase; SMAD: mothers against decapentaplegic; SMC: smooth muscle cell.

proliferation, usually resulting in vascular remodelling and the development of proliferative lesions such as the plexiform structures ${ }^{55}$. Disrupted endothelium leave the underlying vascular tissue defenceless against various blood-borne factors that may further promote pathological changes.

Integrity of the vascular endothelium depends partly on the extent of injury, but also on the capacity for endothelial regeneration and repair following vascular damage. The traditional paradigm of vascular repair is based on the proliferation and migration of pre-existing mature endothelial cells from the adjacent vasculature ${ }^{56}$ (Fig. 4). However, mature endothelial cells are terminally differentiated cells and are thought to have low proliferative potential, with limited capacity to contribute to endothelial reconstruction. In a seminal study, Asahara et al. ${ }^{57}$ described a population of circulating cells that could differentiate into mature endothelial cells ex vivo. These circulating endothelial progenitor cells (EPC) are positive for the stem cell marker CD34 and the VEGF receptor 2 (VEGFR-2). They are thought to originate from the bone marrow, circulate in peripheral blood, and home to sites of endothelial damage where they can differentiate into cells with endothelial-like 
Endothelial regeneration and repair following vascular damage

A) Traditional paradigm of vascular repair (Angiogenesis)

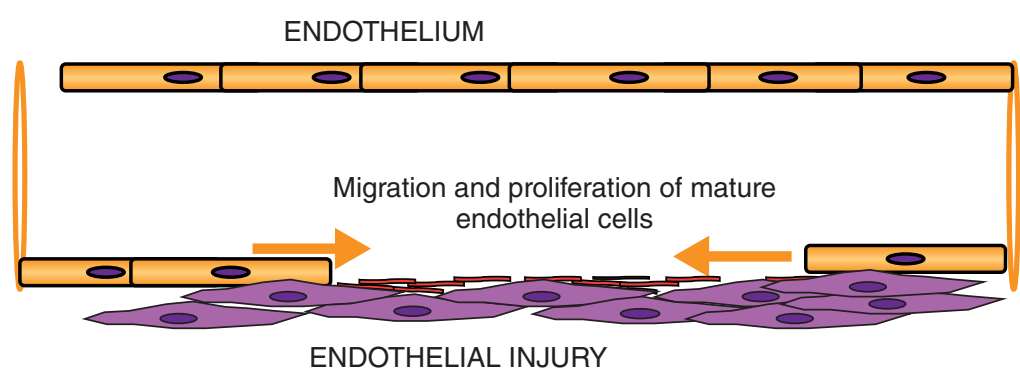

Mature endothelial cells

- Terminally differentiated

- Low proliferative capacity

B) Neo-vasculogenesis

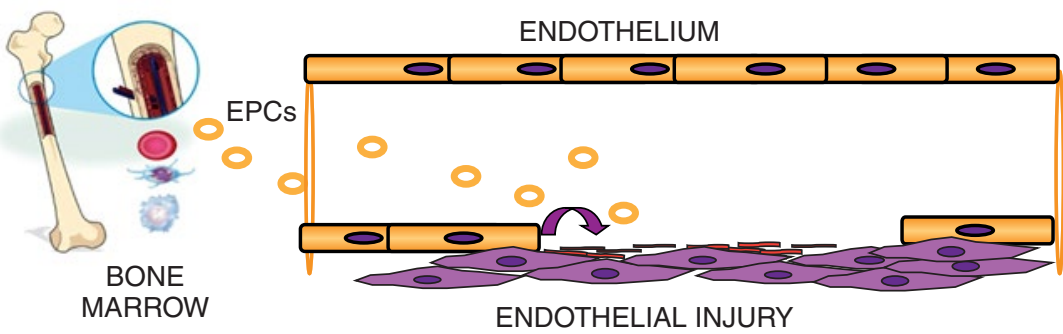

Endothelial progenitor cells (EPCs)

- Home to site of injury

- Facilitate revascularisation

Figure 4. Endothelial regeneration capacity following endothelial injury. A) Traditional paradigm of vascular repair by the locally outgrowth of pre-existing vessels; angiogenesis. B) Neo-vasculogenesis, de novo formation of endothelial cells. Mobilized bone marrow derived endothelial progenitor cells have the capacity to migrate and incorporate into the injured tissue vascular bed.

phenotype to facilitate re-endothelialzation (Fig. 4). The exact origin and phenotype of these progenitors remains uncertain.

It is considered that numbers of circulating EPCs reflect the ability of the organism to repair the endothelium ${ }^{58}$. Reduced number of circulating EPCs has been established as an independent prognostic risk factor associated with endothelial dysfunction and high cardiovascular risk ${ }^{59}$. Therefore, circulating progenitor cells have been suggested as biological markers of vascular dysfunction. Their presence in peripheral circulation offers the opportunity to monitor their number as a marker of disease state and, importantly, as a marker of response to therapy.

Studies of circulating EPCs in $\mathrm{PH}$ have provided conflicting results (Table 2). While some studies indicate greater levels of circulating EPCs in patients with $\mathrm{PH}^{60-62}$, others found that EPCs were reduced compared to controls $^{63-66}$. This discrepancy could be due to methodological differences and failure to reliably match for cardiovascular risk factors, sex, and age. In recent years, the idea that the vasculature is capable of regeneration has raised the possibility that EPC-based therapies may provide an alternative to conventional 
TABLE 2. Putative circulating endothelial progenitor cells in patients with pulmonary hypertension

\begin{tabular}{|c|c|c|c|c|c|c|c|}
\hline $\begin{array}{l}\text { Author } \\
\text { Year }\end{array}$ & Age & Sex & $\begin{array}{l}\text { Disease } \\
\text { type }\end{array}$ & Sample size & $\begin{array}{l}\text { Antibody used } \\
\text { to define an } \\
\text { EPC }\end{array}$ & EPC & CFU-EPC \\
\hline $\begin{array}{l}\text { Asosingh et al. }{ }^{60} \\
2008\end{array}$ & $\begin{array}{l}\text { Matched between } \\
\text { groups }\end{array}$ & $\begin{array}{l}\text { Matched between } \\
\text { groups }\end{array}$ & IPAH & $\begin{array}{l}\text { IPAH }(n=16) \\
\operatorname{HV}(n=16)\end{array}$ & CD34/CD133 & $\mathrm{IPAH}>\mathrm{HV}$ & IPAH $>$ HV \\
\hline $\begin{array}{l}\text { Smadja et al. }{ }^{61} \\
2008\end{array}$ & $\begin{array}{l}\text { Matched between } \\
\text { groups }\end{array}$ & $\begin{array}{l}\text { Matched between } \\
\text { groups }\end{array}$ & PAH/CTEPH & $\begin{array}{l}\text { PAH }(n=9) \\
\text { HV }(n=9)\end{array}$ & $\begin{array}{l}\text { CD146, CD34/ } \\
\text { CD133 }\end{array}$ & $\begin{array}{l}\text { (CD146)-PAH } \\
>\text { HV, CTEPH } \\
\sim \text { HV (CD34/ } \\
\text { CD133)-PAH/ } \\
\text { CTEPH HV }\end{array}$ & $\begin{array}{l}\mathrm{PAH} / \mathrm{CTEPH} \\
\sim \mathrm{HV}\end{array}$ \\
\hline $\begin{array}{l}\text { Toshner et al. }{ }^{62} \\
2009\end{array}$ & $\begin{array}{l}\text { Matched between } \\
\text { groups }\end{array}$ & $\begin{array}{l}\text { Matched between } \\
\text { groups }\end{array}$ & IPAH & $\begin{array}{l}\text { IPAH }(n=7) \\
\text { HV }(n=7)\end{array}$ & $\begin{array}{l}\text { CD34/CD133/ } \\
\text { KDR }\end{array}$ & $\mathrm{IPAH}>\mathrm{HV}$ & $\begin{array}{l}\text { Not } \\
\text { available }\end{array}$ \\
\hline $\begin{array}{l}\text { Fadini et al. }{ }^{63} \\
2007\end{array}$ & Not described & Not available & IPF/PH & $\begin{array}{l}\text { IPF/PAH }(n=5) \\
\text { HV }(n=25)\end{array}$ & $\begin{array}{l}\text { CD34/CD133/ } \\
\text { KDR }\end{array}$ & $\mathrm{IPF} / \mathrm{PAH}<\mathrm{HV}$ & $\begin{array}{l}\text { Not } \\
\text { available }\end{array}$ \\
\hline $\begin{array}{l}\text { Diller et al. }{ }^{64} \\
2008\end{array}$ & $\begin{array}{l}\text { Matched between } \\
\text { groups }\end{array}$ & $\begin{array}{l}\text { Matched between } \\
\text { groups }\end{array}$ & IPAH & $\begin{array}{l}\text { IPAH }(n=55) \\
\text { HV }(n=47)\end{array}$ & CD34/KDR & $\mathrm{IPAH}<\mathrm{HV}$ & $\mathrm{IPAH}>\mathrm{HV}$ \\
\hline $\begin{array}{l}\text { Junhui et al. }{ }^{65} \\
2008\end{array}$ & $\begin{array}{l}\text { Matched between } \\
\text { groups }\end{array}$ & $\begin{array}{l}\text { Matched between } \\
\text { groups }\end{array}$ & IPAH & $\begin{array}{l}\text { IPAH }(n=20) \\
\text { HV }(n=20)\end{array}$ & CD133/KDR & IPAH $<$ HV & $\begin{array}{l}\text { Not } \\
\text { analysed }\end{array}$ \\
\hline $\begin{array}{l}\text { Hansmann et al. } \\
2011\end{array}$ & $\begin{array}{l}\text { Matched between } \\
\text { groups }\end{array}$ & $\begin{array}{l}\text { Matched between } \\
\text { groups }\end{array}$ & PAH & $\begin{array}{l}\text { IPAH }(n=43) \\
\text { HV }(n=6)\end{array}$ & CD34/KDR & $\mathrm{IPAH}<\mathrm{HV}$ & $\begin{array}{l}\text { Not } \\
\text { analysed }\end{array}$ \\
\hline
\end{tabular}

CFU-EPC: endothelial outgrowth colony-forming units; CTEPH: chronic thromboembolic pulmonary hypertension; EPC: endothelial progenitor cell; HV: healthy volunteers; IPAH: idiopathic pulmonary arterial hypertension; IPF: idiopathic pulmonary fibrosis; KDR: kinase insert domain receptor; PAH: pulmonary artery hypertension.

treatments. Despite this ambiguity, ex vivo expanded endothelial-like progenitor cells have shown therapeutic benefit in short-term studies in animal models of $\mathrm{PH}^{67,68}$ and in a randomized controlled trial in humans with idiopathic $\mathrm{PAH}^{69}$. Whether decreased vascular damage is caused by a direct endothelial repair by EPCs or indirectly by the release of paracrine signals is unknown. At present, it is too premature to draw any definitive conclusion as to the utility of EPCs in PH treatment. Additional evidence is required to better define and understand the role of EPC as a biomarker or diagnostic tool and to understand its physiological and functional characteristics in $\mathrm{PH}$.

An accurate assessment of the severity of endothelial dysfunction may have diagnostic and prognostic value for PH. Thus, it is important to identify novel circulating biological targets in blood that specifically indicate the pathologic mechanism, the severity of the disease, and the treatment response. Novel potential biomarkers, such as endothelium-derived microparticles (EMP), have been recently suggested as alternative indicators of endothelial dysfunction in PH. The EMPs are small membrane vesicles released from endothelial cells in response to cell activation, damage, or apoptosis ${ }^{70}$. Patients with $\mathrm{PH}$ show higher numbers of circulating EMPs, thereby reflecting the patient's endothelial impairment ${ }^{71}$. They also have been correlated to some extent with established parameters of endothelial dysfunction, vascular damage, and disease severity ${ }^{71}$.

As endothelial dysfunction is a major determinant in the design of new therapeutic drugs, 


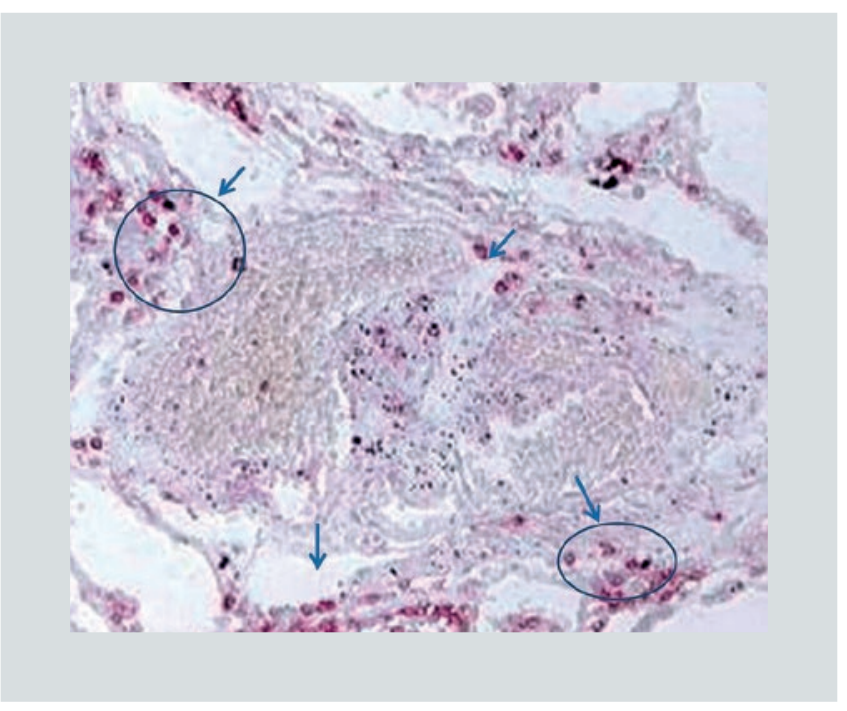

Figure 5. Perivascular CD45+ inflammatory cells (arrows) in a plexiform lesion from a patient with pulmonary arterial hypertension.

understanding mechanisms of endothelial repair is critical towards developing a cure based on PH-targeted therapies. The combined assessment of potential surrogate markers for vascular dysfunction and early detection (EMPs and EPCs) could therefore provide valuable information about the patient's endothelial impairment, endogenous repair capacity, and disease severity.

\section{INFLAMMATION}

Inflammatory mechanisms appear to play a significant role in some types of $\mathrm{PH}$, including monocrotaline-induced $\mathrm{PH}$ in rats and $\mathrm{PAH}$ of various origins in humans, including connective tissue diseases and human immunodeficiency virus (HIV) infection ${ }^{72}$. In fact, a wide range of cytokines has been shown to be elevated and to correlate with survival in $\mathrm{PAH}^{73}$. As is well documented in tissue-based studies, both early and persistent inflammation contributes to pulmonary vascular disease. The idea of an inflammatory process as a mechanism of vascular remodelling derived from studies demonstrating an increased number of inflammatory cells infiltrating the adventitia of pulmonary arteries in many forms of $\mathrm{PH}$ (Fig. 5). In these studies, the amount of perivascular inflammatory infiltrate, largely of lymphocytes, correlated with parameters of pulmonary vascular remodelling and haemodynamics in $\mathrm{PH}^{74}$. In perivascular tissues from subjects with $\mathrm{PH}$, the most common cellular components of inflammation are described ${ }^{72}$ : macrophages (CD68, CD14), dendritic cells (CD209), T-lymphocytes (CD3, CD4 and CD8) are usually increased as compared with control subjects ${ }^{75}$. The action of secreted cytokines, including TGF- $\beta$, in the adventitia mediates specific homing for leukocytes in this vascular compartment, leading to their inappropriate/ pathologic retention and survival ${ }^{76}$. The adventitia is, therefore, suited to harbour canonical innate immune cells, specifically macrophages and dendritic cells, which with adventitial fibroblasts, are all equipped with the necessary machinery (e.g., toll-like receptors and inflammasome components [like the nod-like receptors]) to potently respond to a variety of exogenous and endogenous danger signals.

The innate inflammatory system appears to also participate in PH. Natural killer cells, which target stressed, virally infected, or oncogenically transformed cells, are dysfunctional, with reduced number and cytolytic capacity, in patients with idiopathic PAH and in mouse and rat models of $\mathrm{PH}^{77}$. The complement system, which bridges innate and adaptive immunity, is also activated in $\mathrm{PAH}$, and deficiency of complement $\mathrm{C} 3$ protects mice from hypoxia-induced $\mathrm{PH}^{78}$. 
Finally, inflammation is closely associated with pulmonary vascular disease in the setting of autoimmune diseases, such as scleroderma, and paradigmatic of the interplay of inflammation and $\mathrm{PH}$ is its link with schistosomiasis (the most frequent cause of $\mathrm{PAH}$ worldwide $^{79}$ and HIV infection ${ }^{80}$.

A further pathway by which remote signalling might target the pulmonary vasculature is by the release of cell-derived exosomes from distant sources, exerting anti- or proinflammatory depending on their cargo. Exosomes derived from mesenchymal stem cells were found to inhibit the hypoxic activation of the signal transducers and activators of transcription 3 (STAT3) pathway in hypoxic mice and prevent the development of $\mathrm{PH}^{81}$.

\section{CONCLUSIONS}

In summary, multiple factors are involved in the pathobiology of $\mathrm{PH}$. The progression of the disease is driven by a combination of changes in the balance of vasoactive mediators, altered cell proliferation and apoptosis, dysfunctional endothelial repair and angiogenesis, and contributing factors such as inflammation. The past decade has witnessed major therapeutic advances in the treatment of $\mathrm{PH}$ and currently available pharmacological agents have provided significant improvement in survival and wellbeing of patients. Yet, further progression in the understanding of the molecular mechanisms underlying vascular changes in $\mathrm{PH}$ will furnish the basis for future innovative approaches to the treatment of this devastating disease.

\section{CONFLICT OF INTEREST}

Dra. I. Blanco reports personal fees from Bayer, personal fees from Actelion, outside the submitted work. Dr. Barberà reports personal fees from Actelion, personal fees from Bayer, personal fees from GlaxoSmithKline, personal fees from Pfizer, grants from Actelion, grants from Bayer, grants from GlaxoSmithKline, grants from Pfizer, outside the submitted work. All other authors declare no relevant conflict of interest.

\section{REFERENCES}

1. Simonneau G, Gatzoulis MA, Adatia I, et al. Updated clinical classification of pulmonary hypertension. J Am Coll Cardiol. 2013;62:D34-41.

2. Ghofrani HA, Pepke-Zaba J, Barbera JA, et al. Nitric oxide pathway and phosphodiesterase inhibitors in pulmonary arterial hypertension. J Am Coll Cardiol. 2004;43:68-72S.

3. Giaid A, Saleh D. Reduced expression of endothelial nitric oxide synthase in the lungs of patients with pulmonary hypertension. N Engl J Med. 1995;333:214-21.

4. Pullamsetti S, Kiss L, Ghofrani HA, et al. Increased levels and reduced catabolism of asymmetric and symmetric dimethylarginines in pulmonary hypertension. FASEB J. 2005;19:1175-7.

5. Galie N, Corris PA, Frost A, et al. Updated treatment algorithm of pulmonary arterial hypertension. J Am Coll Cardiol. 2013;62:D60-72.

6. Ghofrani HA, Galie N, Grimminger F, et al. Riociguat for the treatment of pulmonary arterial hypertension. N Engl J Med. 2013;369:330-40.

7. Giaid A, Yanagisawa M, Langblen D, et al. Expression of endothelin-1 in the lungs of patients with pulmonary hypertension. N Engl J Med. 1993;328:1732-9.

8. Wilkins MR. Pulmonary hypertension: the science behind the disease spectrum. Eur Respir Rev. 2012;21:19-26.

9. Abraham D, Ponticos M, Nagase H. Connective tissue remodeling: crosstalk between endothelins and matrix metalloproteinases. Curr Vasc Pharmacol. 2005;3:369-79.

10. Pulido T, Adzerikho I, Channick RN, et al. Macitentan and morbidity and mortality in pulmonary arterial hypertension. N Engl J Med. 2013;369:809-18.

11. Tuder RM, Cool CD, Geraci MW, et al. Prostacyclin synthase expression is decreased in lungs from patients with severe pulmonary hypertension. Am J Respir Crit Care Med. 1999;159:1925-32.

12. McLaughlin VV, Channick RN, Chin K, et al. Effect of Selexipag on morbidity/mortality in pulmonary arterial hypertension: Results of the GRIPHON study. J Am Coll Cardiol. 2015;65:A1538-8.

13. Herve P, Launay JM, Scrobohaci ML, et al. Increased plasma serotonin in primary pulmonary hypertension. Am J Med. 1995;99:249-54.

14. Guignabert C, Raffestin B, Benferhat R, et al. Serotonin transporter inhibition prevents and reverses monocrotaline-induced pulmonary hypertension in rats. Circulation. 2005;111:2812-19.

15. Hossein AG, Hikmet A, Anton V, et al. Proof-Of-Concept study to investigate the efficacy, hemodynamics and tolerability of terguride vs. placebo in subjects with pulmonary arterial hypertension: Results of a double blind, randomised, prospective phase IIa study. Am J Respir Crit Care Med. 2012;187:A2496. 
16. Mandegar M, Yuan JX. Role of K+ channels in pulmonary hypertension. Vascul Pharmacol. 2002;38:25-33.

17. Schermuly RT, Ghofrani HA, Wilkins MR, Grimminger F. Mechanisms of disease: pulmonary arterial hypertension. Nat Rev Cardiol. 2011; 8:443-55.

18. Morrell NW, Adnot S, Archer SL, et al. Cellular and molecular basis of pulmonary arterial hypertension. J Am Coll Cardiol. 2009;54:S20-31.

19. Yu Y, Fantozzi I, Remillard CV, et al. Enhanced expression of transient receptor potential channels in idiopathic pulmonary arterial hypertension. Proc Natl Acad Sci USA. 2004;101:13861-6.

20. Humbert M, Lau EM, Montani D, Jais X, Sitbon O, Simonneau G. Advances in therapeutic interventions for patients with pulmonary arterial hypertension. Circulation. 2014;130:2189-208.

21. Jeffery TK, Morrell NW. Molecular and cellular basis of pulmonary vascular remodeling in pulmonary hypertension. Prog Cardiovasc Dis. 2002;45:173-202.

22. Voelkel NF, Cool C, Lee SD, Wright L, Geraci MW, Tuder RM. Primary pulmonary hypertension between inflammation and cancer. Chest. 1998;114:225-30S

23. Cool CD, Stewart JS, Werahera P, et al. Three-dimensional reconstruction of pulmonary arteries in plexiform pulmonary hypertension using cell-specific markers. Evidence for a dynamic and heterogeneous process of pulmonary endothelial cell growth. Am J Pathol. 1999;155:411-19.

24. Morrell NW, Yang X, Upton PD, et al. Altered growth responses of pulmonary artery smooth muscle cells from patients with primary pulmonary hypertension to transforming growth factor-beta(1) and bone morphogenetic proteins. Circulation. 2001;104:790-5.

25. Humbert M, Monti G, Fartoukh M, et al. Platelet-derived growth factor expression in primary pulmonary hypertension: comparison of HIV seropositive and HIV seronegative patients. Eur Respir J. 1998; 11:554-9.

26. Schermuly RT, Dony E, Ghofrani HA, et al. Reversal of experimental pulmonary hypertension by PDGF inhibition. J Clin Invest. 2005; 115:2811-21.

27. Merklinger SL, Jones PL, Martinez EC, Rabinovitch M. Epidermal growth factor receptor blockade mediates smooth muscle cell apoptosis and improves survival in rats with pulmonary hypertension. Circulation. 2005; 112:423-31

28. Sakao S, Taraseviciene-Stewart L, Cool CD, et al. VEGF-R blockade causes endothelial cell apoptosis, expansion of surviving CD34+ precursor cells and transdifferentiation to smooth muscle-like and neuronal-like cells. FASEB J. 2007;21:3640-52.

29. Tuder RM, Chacon M, Alger L, et al. Expression of angiogenesis-related molecules in plexiform lesions in severe pulmonary hypertension: Evidence for a process of disordered angiogenesis. J Pathol. 2001;195:367-74.

30. Wanstall JC, Gambino A, Jeffery TK, et al. Vascular endothelial growth factor-B-deficient mice show impaired development of hypoxic pulmonary hypertension. Cardiovasc Res. 2002;55:361-8.

31. Hoeper MM, Barst RJ, Bourge RC, et al. Imatinib mesylate as add-on therapy for pulmonary arterial hypertension: results of the randomized IMPRES study. Circulation. 2013;127:1128-38.

32. Dahal BK, Cornitescu T, Tretyn A, et al. Role of epidermal growth factor inhibition in experimental pulmonary hypertension. Am J Respir Crit Care Med. 2010;181:158-67.

33. Izikki M, Guignabert C, Fadel E, et al. Endothelial-derived FGF2 contributes to the progression of pulmonary hypertension in humans and rodents. J Clin Invest. 2009;119:512-23.

34. Du L, Sullivan CC, Chu D, et al. Signaling molecules in nonfamilial pulmonary hypertension. N Engl J Med. 2003;348:500-9.

35. Sullivan CC, Du L, Chu D, et al. Induction of pulmonary hypertension by an angiopoietin 1/TIE2/serotonin pathway. Proc Natl Acad Sci USA. 2003;100:12331-6.

36. Duffy MJ, O'Donovan N, Brennan DJ, Gallagher WM, Ryan BM. Survivin: a promising tumor biomarker. Cancer Lett. 2007;249:49-60.
37. Liu X, Ryland L, Yang J, et al. Targeting of survivin by nanoliposomal ceramide induces complete remission in a rat model of NK-LGL leukemia. Blood. 2010;116:4192-201.

38. Tao YF, Lu J, Du XJ, et al. Survivin selective inhibitor YM155 induce apoptosis in SK-NEP-1 Wilms tumor cells. BMC Cancer. 2012;12:619.

39. Satoh T, Okamoto I, Miyazaki M, et al. Phase I study of YM155, a novel survivin suppressant, in patients with advanced solid tumors. Clin Cancer Res. 2009;15:3872-80.

40. Tolcher AW, Quinn DI, Ferrari A, et al. A phase II study of YM155, a novel small-molecule suppressor of survivin, in castration-resistant taxane-pretreated prostate cancer. Ann Oncol. 2012;23:968-73.

41. McMurtry MS, Archer SL, Altieri DC, et al. Gene therapy targeting survivin selectively induces pulmonary vascular apoptosis and reverses pulmonary arterial hypertension. J Clin Invest. 2005;115:1479-91.

42. Blanc-Brude OP, Yu J, Simosa H, Conte MS, Sessa WC, Altieri DC. Inhibitor of apoptosis protein survivin regulates vascular injury. Nat Med. 2002; 8:987-94.

43. Miyazono K, Maeda S, Imamura T. BMP receptor signaling: transcriptional targets, regulation of signals, and signaling cross-talk. Cytokine Growth Factor Rev. 2005;16:251-63.

44. Tuder RM, Archer SL, Dorfmuller P, et al. Relevant issues in the pathology and pathobiology of pulmonary hypertension. J Am Coll Cardiol. 2013; 62:D4-12.

45. Sztrymf B, Yaici A, Girerd B, Humbert M. Genes and pulmonary arterial hypertension. Respiration. 2007;74:123-32.

46. Sztrymf B, Coulet F, Girerd B, et al. Clinical outcomes of pulmonary arterial hypertension in carriers of BMPR2 mutation. Am J Respir Crit Care Med. 2008;177:1377-83.

47. Girerd B, Montani D, Coulet F, et al. Clinical outcomes of pulmonary arterial hypertension in patients carrying an ACVRL1 (ALK1) mutation. Am J Respir Crit Care Med. 2010;181:851-61.

48. Chaouat A, Coulet F, Favre C, et al. Endoglin germline mutation in a patien with hereditary haemorrhagic telangiectasia and dexfenfluramine associated pulmonary arterial hypertension. Thorax. 2004;59:446-48.

49. Nasim MT, Ogo T, Ahmed M, et al. Molecular genetic characterization of SMAD signaling molecules in pulmonary arterial hypertension. Hum Mutat. 2011;32:1385-9.

50. Shintani M, Yagi H, Nakayama T, Saji T, Matsuoka R. A new nonsense mutation of SMAD8 associated with pulmonary arterial hypertension. Med Genet. 2009;46:331-7.

51. Austin ED, Ma L, LeDuc C, et al. Whole exome sequencing to identify a novel gene (caveolin-1) associated with human pulmonary arterial hypertension. Circ Cardiovasc Genet. 2012;5:336-43.

52. Ma L, Roman-Campos D, Austin ED, et al. A novel channelopathy in pulmonary arterial hypertension. N Engl J Med. 2013;369:351-61.

53. Cines DB, Pollak ES, Buck CA, et al. Endothelial cells in physiology and in the pathophysiology of vascular disorders. Blood. 1998;91:3527-61.

54. Barst R. Is it possible to reverse the endothelial dysfunction in pulmonary arterial hypertension? J Am Coll Cardiol. 2007;49:1572-4.

55. Budhiraja R, Tuder RM, Hassoun PM. Endothelial dysfunction in pulmonary hypertension. Circulation. 2004;109:159-65.

56. Risau W, Flamme I. Vasculogenesis. Annu Rev Cell Dev Biol. 1995;11:73-91.

57. Asahara T, Murohara T, Sullivan A, et al. Isolation of putative progenitor endothelial cells for angiogenesis. Science. 1997;275:964-7.

58. Burger D, Touyz RM. Cellular biomarkers of endothelial health: microparticles, endothelial progenitor cells, and circulating endothelial cells. J Am Soc Hypertens. 2012;6:85-99.

59. Schmidt-Lucke C, Rossig L, Fichtlscherer S, et al. Reduced number of circulating endothelial progenitor cells predicts future cardiovascular events: proof of concept for the clinical importance of endogenous vascular repair. Circulation. 2005;111:2981-7.

60. Asosingh K, Aldred MA, Vasanji A, et al. Circulating angiogenic precursors in idiopathic pulmonary arterial hypertension. Am J Pathol. 2008 172:615-27. 
61. Smadja DM, Mauge L, Sanchez O, et al. Distinct patterns of circulating endothelial cells in pulmonary hypertension. Eur Respir J. 2010;36: 1284-93.

62. Toshner M, Voswinckel R, Southwood M, et al. Evidence of dysfunction of endothelial progenitors in pulmonary arterial hypertension. Am J Respir Crit Care Med. 2009;180:780-7.

63. Fadini GP, Schiavon M, Avogaro A, Agostini C. The emerging role of endothelial progenitor cells in pulmonary hypertension and diffuse lung diseases. Sarcoidosis Vasc Diffuse Lung Dis. 2007;24:85-93.

64. Diller GP, van ES, Okonko DO, et al. Circulating endothelial progenitor cells in patients with Eisenmenger syndrome and idiopathic pulmonary arterial hypertension. Circulation. 2008;117:3020-30.

65. Junhui Z, Xingxiang W, Guosheng F, Yunpeng S, Furong Z, Junzhu C. Reduced number and activity of circulating endothelial progenitor cells in patients with idiopathic pulmonary arterial hypertension. Respir Med. 2008;102:1073-9.

66. Hansmann G, Plouffe BD, Hatch A, et al. Design and validation of an endothelial progenitor cell capture chip and its application in patients with pulmonary arterial hypertension. J Mol Med (Berl). 2011;89:971-83.

67. Zhao YD, Courtman DW, Deng Y, Kugathasan L, Zhang Q, Stewart DJ. Rescue of monocrotaline-induced pulmonary arterial hypertension using bone marrow-derived endothelial-like progenitor cells: efficacy of combined cell and eNOS gene therapy in established disease. Circ Res. 2005;96:442-50.

68. Takahashi M, Nakamura T, Toba T, Kajiwara N, Kato H, Shimizu Y. Transplantation of endothelial progenitor cells into the lung to alleviate pulmonary hypertension in dogs. Tissue Eng. 2004;10:771-9.

69. Wang XX, Zhang FR, Shang YP, et al. Transplantation of autologous endothelial progenitor cells may be beneficial in patients with idiopathic pulmonary arterial hypertension: a pilot randomized controlled trial. J Am Coll Cardiol. 2007;49:1566-71.

70. VanWijk MJ, VanBavel E, Sturk A, Nieuwland R. Microparticles in cardiovascular diseases. Cardiovasc Res. 2003;59:277-87.
71. Rame JE, Vaidya A. Disease progression in pulmonary arterial hypertension: refining the phenotype with a prognostic biomarker profile from collagen. JACC Heart Fail. 2014;2:422-4.

72. Dorfmuller P, Perros F, Balabanian K, Humbert M. Inflammation in pulmonary arterial hypertension. Eur Respir J. 2003;22:358-63.

73. Soon E, Holmes AM, Treacy CM, et al. Elevated levels of inflammatory cytokines predict survival in idiopathic and familial pulmonary arterial hypertension. Circulation. 2010;122:920-7.

74. Peinado VI, Gomez FP, Barbera JA, et al. Pulmonary vascular abnormalities in chronic obstructive pulmonary disease undergoing lung transplant. Heart Lung Transplant. 2013;32:1262-9.

75. Savai R, Pullamsetti SS, Kolbe J, et al. Immune and inflammatory cell involvement in the pathology of idiopathic pulmonary arterial hypertension. Am J Respir Crit Care Med. 2012;186:897-908.

76. Buckley CD, Pilling D, Lord JM, Akbar AN, Scheel-Toellner D, Salmon M. Fibroblasts regulate the switch from acute resolving to chronic persistent inflammation. Trends Immunol. 2001;22:199-204.

77. Ormiston ML, Chang C, Long LL, et al. Impaired natural killer cell phenotype and function in idiopathic and heritable pulmonary arterial hypertension. Circulation. 2012;126:1099-109.

78. Bauer EM, Zheng H, Comhair S, Erzurum S, Billiar TR, Bauer PM. Complement C3 deficiency attenuates chronic hypoxia-induced pulmonary hypertension in mice. PLoS One. 2011;6:e28578.

79. Graham BB, Bandeira AP, Morrell NW, Butrous G, Tuder RM. Schistosomiasis-associated pulmonary hypertension: pulmonary vascular disease: the global perspective. Chest. 2010;137:20-9S.

80. Almodovar S, Knight R, Allshouse AA, et al. Human Immunodeficiency Virus nef signature sequences are associated with pulmonary hypertension. AIDS Res Hum Retroviruses. 2012;28:607-18.

81. Lee C, Mitsialis SA, Aslam M, et al. Exosomes mediate the cytoprotective action of mesenchymal stromal cells on hypoxia-induced pulmonary hypertension. Circulation. 2012;126:2601-11. 